DOI:10.24193/tras.57E.1

Published First Online: 06/25/2019

\title{
POLICY ALIENATION AMONG EMPLOYEES OF THE LABOR OFFICE OF THE CZECH REPUBLIC
}

\section{Michaela HIEKISCHOVÁ}

\section{Michaela HIEKISCHOVÁ}

Lecturer and researcher, Faculty

of Social and Economic Studies,

Abstract

Currently, there is intense debate about what determines the difference between a policy failure and a policy success. In this article we assume that top-down policy design is a poor manner of decision-making and that without the involvement of employees (public professionals) who identify with new policies, policy failure is likely. Therefore, we concentrate our attention on public professionals (and their opinions, perceptions, and feelings) applying the concept of policy alienation developed by Lars Tummers. In particular, this paper deals with the consequences of reform in the labor offices of the Czech Republic for the employees of these institutions. This reform was a top-down policy designed without communication or discussion with stakeholders. The reform led to a number of problems, some of which originated in the policy-making process, and others of which arose in the implementation of the reforms. In this article, we explore the hypothesis that employees who were not consulted or involved in the design and implementation of the reforms suffered from feelings of policy alienation. Our research is based on quantitative methods and we apply a reliable, validated policy alienation scale created by Lars Tummers. We also assume that there is a relationship between policy alienation and job satisfaction, and between policy alienation and commitment to the aims of the organization.

Keywords: labor office, policy alienation, job satisfaction, organizational commitment, public professionals.

Jan Evangelista Purkyně University, Ústí and Labem,

Czech Republic

Tel.: 00420-604-385.854

E-mail: michaela.hiekischova@ujep.cz
* Acknowledgement: This paper was supported by the Faculty of Social and Economic Studies of the Jan Evangelista Purkyně University in Ústí and Labem (Project no. UJEPIGS-2018-45-001-1).

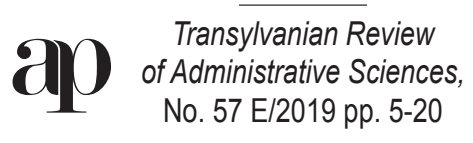




\section{Introduction}

This paper deals with the consequences of reform of the labor offices in the Czech Republic for the employees of those institutions. We consider this reform to be an example of a policy failure. The decision-making process for the reform had a top-down design that lacked communication or discussion with the employees of the labor offices. The reform caused many problems. We assume that without the involvement of the employees of the labor offices as professional public servants in the design and implementation of the new policies, they could not be successful. In short, one of the causes of that policy failure was lack of communication and discussion by management with the employees who would have to implement the new program. This led to alienation of the employees from the policy and consequently to low job satisfaction and low organizational commitment. We focus only on one element of this policy failure, lack of communication and discussion with employees, the importance of which has been highlighted by many experts, e.g., Bovens and 't Hart (2011), McConnell (2015), Bovens, 't Hart and Peters (2001).

The major goal of this article is to learn whether we can use Tummers's previously validated scale for measurement of policy alienation under different conditions, that is, in different history, cultures, target groups, and public domains. The Czech Republic was part of the Soviet Bloc (from 1968 to 1989). The regime was autocratic and this long experience can currently influence the present policy-making process (its formal and informal rules). We have not found any article in the literature on policy alienation in the Czech Republic and in other states of Central and Eastern Europe. In the West, however, the concept is often discussed (see, for example, van Engen, 2017). We consider the examination of policy alienation in the Czech and Eastern European context to be the first contribution of this article.

This article's second contribution is related to the assumption that policy alienation influences job satisfaction. Like Tummers (2012 and 2013), we want to find out whether and to what extent job satisfaction is influenced by the degree each of the sub-dimensions of policy alienation is present among employees. We assume that the links between the policy level (particularly the implementation level) and the psychological level in the minds of employees are very important and studying them can offer a new perspective to policy-makers.

A third dimension, the employees' commitment to the organization ('organizational commitment') is also related to the assumption that policy alienation affects job satisfaction. Organizational commitment has not yet been studied in relation to policy alienation. We consider our examination of that relationship to be a third contribution of this paper, because we believe that the several sub-dimensions of policy alienation negatively influence organizational commitment as much as they do job satisfaction. We would like to find out whether and to what extent that is true.

In general, our paper is based on an assumption that without communication by managers, top-down policy-making leads to a high degree of policy alienation among employees, stemming particularly from their powerlessness to affect poli- 
cy and the lack of meaningful input they are allowed to provide to policy-makers (Tummers, 2012). We believe such feelings can cause low job satisfaction and low organizational commitment. In the end, those feelings impact performance of the employee's duties and the employee's attitude toward their clients (Farmer, 2011; Cole, Panchanadeswaran and Daining, 2004). This article is focused on the policy level and on the impact of policy-making on employees. We believe that the policy level is as important as the organizational level (see, e.g., Asencio, 2016; Mendes, Carlos and Lourenco, 2014).

This article is structured as follows: first, we provide a brief overview of the reform of the labor offices. Second, we discuss the theoretical framework, which predicts policy alienation and its impact on job satisfaction and organizational commitment. Third, we use a quantitative approach, analyzing a survey of 1,334 employees of the labor offices who work in the employment department and the non-insurance social benefits department. Our analysis is based on descriptive statistics, correlation and linear regression. In the conclusion, we discuss the contributions of this paper to the literature.

\section{Brief overview of the government's reform of the labor offices}

In 2011, the Czech government introduced an organizational reform of the labor offices under the Ministry of Labor and Social Affairs. This reform was extensive and focused on two functions of the labor offices. The first area was employment assistance and the second was non-insurance social benefits (particularly need-based payments and disability benefits).

The first stage of the reform concentrated on the organizational structure. It meant a big change in that structure, from decentralized to centralized control. Seventy-seven labor offices, each of which had been its own legal entity, were transformed into one centralized Labor Office of the Czech Republic. We analyzed and explored the history of these state institutions from their establishment in 1990, when the labor offices were set up with a decentralized structure. In this time, they realized their own local labor policy (they were allowed to adapt their internal policies to their clients - the unemployed and companies) and we can say that the labor offices created a productive and competitive local labor market. They independently provided public employment services, mainly job brokerage, active labor policies, and administration and management of unemployment benefits. The reform was unexpected and unwanted by the Labor Office employees.

The second stage of the reform involved changes in the content of the public employment services provided by the labor offices. The new services were all non-insurance social benefits (particularly need-based payments and disability benefits). Before their addition to the labor offices' activities they were provided by municipalities. The basic goals of the reform were to unify the agency's structure and decision-making, and to increase savings, efficiency and effectiveness. These goals can be viewed as resulting from the influence of the 'new public management'. 
The whole reform ran into a number of problems during the approval process and its implementation. The approval process is generally considered to have been too quick, non-standard and unprepared. Stakeholders complained that during the decision-making process, communication from management was lacking, the controlling legislation was poorly drafted, and the timing of the reform was ill-considered (during the worldwide financial crisis). The stakeholders disputed the contention by the proponents of the reform that it would lead to budgetary savings. Implementation problems included the dismissal of many employees resulting in a labor shortage in the offices, an untested and unworkable new integrated ICT system and inappropriate space in the offices (see also e.g., Kotrusová and Výborná, 2015).

\section{Policy alienation}

The theory of 'policy alienation' was developed by Lars Tummers and his colleagues, Victor Bekkers and Bram Steijn (Tummers, Bekkers and Steijn, 2009, 2012; Tummers, 2012; Tummers, 2013). They assume that professionals are alienated from a policy if they have difficulty in personally identifying with its goals, which frequently focus primarily on efficiency and financial transparency. The concept of policy alienation is based on the assumption that professionals want to participate in decision-making with regard to policies which they will have to implement. They want to be autonomous and provide society and their clients with added value. If they cannot do that, they become stressed, frustrated and dissatisfied with their jobs. They feel powerless in the implementation of the policy and find the policy to be meaningless to them (for more also, see, e.g., Elpers and Westhuis, 2008; Farmer, 2011).

The theory of policy alienation is based on the sociological theory of work alienation, as well as on theoretical concepts of bureaucracy and policy implementation. One of the early, key writers on worker alienation was Karl Marx (1961) who connected work alienation with economic factors (the main cause is capitalism and private ownership) and with objective meaning. Objective work alienation means that workers do not consciously feel that they are alienated, but because they do not own the product of their labor or the means of production, they objectively are in fact alienated. In contrast to Marx, current scholars focus more on subjective work alienation (that is, how much alienated workers actually feel they are from their work). The most important paper about subjective work alienation is by Melvin Seeman (1959). He theorized precisely five basic dimensions of alienation: powerlessness, meaninglessness, normlessness, isolation and self-estrangement. These categories are all significant in theory, but each subsequent researcher has focused on a different, convenient dimension in his or her study for empirical investigation. Another author, Robert Blauner (1964), followed up Seeman's work, and distinguished only four dimensions of work alienation: powerlessness, meaninglessness, isolation and self-estrangement. Like Blauner and Seeman, Lars Tummers and his colleagues (2009) suppose that alienation is a multidimensional concept. Tummers however focuses on policy alienation, whereas Blauner remains focused on work alienation. We can call both concepts forms of 'local alienation' (Kalekin-Fishman, 2000). 
According to Tummers, policy alienation is prevalent in the public domain, where public professionals implement public policies. He defines policy alienation as 'a general cognitive state of psychological disconnection from the policy program being implemented, here by a public professional who regularly interacts directly with clients' (Tummers, Bekkers and Steijn, 2009, p. 688). He defines public professionals relatively broadly. They are professionals who work in the public sector, or in a sector that is heavily regulated or subsidized by the state in the public interest. Public professionals implement public policies. As they do so, they interact directly with clients on a regular basis. According to Tummers (2013), public professionals are a broadly defined group of workers that may include medical specialists, teachers, police officers, clerks, and social workers.

As mentioned above, the theory of policy alienation is rooted in concepts of bureaucracy and policy implementation. In this field, Michael Lipsky is interested in the role played by public servants in implementing policies. In his book, he developed a theory of 'street-level bureaucrats'. Street-level bureaucrats are those employees who 'interact directly with citizens in the course of their jobs, and who have substantial discretion in the execution of their work' (Lipsky, 1980, p. 3). But Lipsky says they have some intrinsic problems, mainly when confronted with a top-down approach to policy design and implementation. According to him, street-level bureaucrats become alienated when they are not able to control the pace of their work and when they work only on discrete segments of the organization's products.

As mentioned above, Tummers began to explore alienation in relation to policy, not the work itself. The first two articles he co-authored applied a qualitative methodology (Tummers, Bekkers and Steijn, 2009, 2012). The authors investigated physicians and secondary school teachers, and their dissatisfaction and alienation toward policies they had to implement. Tummers (2012) subsequently created a validated scale to measure policy alienation. This scale has two dimensions: policy powerlessness and policy meaninglessness.

Policy powerlessness 'relates to the degree of influence that public professionals have over shaping a policy program' (Tummers, 2012, p. 518). It is connected with the field of policy formulation and implementation. This major dimension consists of three sub-dimensions: strategic, tactical, and operational. Strategic powerlessness refers to the influence professionals perceive they have on decision-making as it concerns the content of policy. Tactical powerlessness refers to the influence professionals perceive they have on decisions about how a policy is executed by their institution. Operational powerlessness refers to the influence professionals perceive they have on the implementation of policy (Tummers, 2012, 2013).

Policy meaninglessness is connected to understanding the policy that employees are meant to implement. This second major dimension consists of two sub-dimensions: societal and client meaninglessness. Societal meaninglessness refers to a perception by professionals that the goals of new policies are not valuable to society or that it is not possible to achieve the goals. Client meaninglessness relates to the per- 
ception by professionals that a new policy is not providing added value for their clients (Tummers, 2012, 2013).

\section{Policy alienation and its relation to job satisfaction}

Job satisfaction is usually categorized as a topic for research in psychology or sociology. It is rarely linked to the field of policy design and implementation. With regard to job satisfaction, the psychological and sociological perspectives, on the one hand, and the policy and political perspectives, on the other, might seem unrelated at first sight. This may be because 'job satisfaction is analyzed on the job level, while policy alienation is analyzed on the more specific policy level' (Tummers, 2013, p. 47). However, it has recently been demonstrated that participation in policy-making by employees is likely to have a positive effect on job satisfaction (Elpers and Westhuis, 2008; DeHart-Davis and Pandey, 2005; Aiken and Hage, 1966). Conversely, we can say that job dissatisfaction can result from policy alienation.

Nevertheless, the link between participation in policy-making and job satisfaction is complicated, and it certainly should not be assumed that participation by employees is the only factor that influences job satisfaction. On the other hand, it is plausible to assume that if a policy is designed without regard for the perspectives and experiences of the professionals who must implement it, those professionals are more likely to feel alienation from the policy and their work, and more likely to have lower feelings of organizational commitment and job satisfaction. In this context (in Tummers's conceptualization), the theory is based on the idea that employees have the right to provide input into decisions that affect their lives.

When we consider the relationship between strategic powerlessness and job satisfaction, we would expect that public professionals who are not able to influence policy design will feel more job dissatisfaction. When we examine the relationship between tactical powerlessness and job satisfaction, we would suppose that public professionals who are not involved in policy-making and who do not take part in discussions about the execution of a new policy will be more dissatisfied with their jobs. Next, when we consider the relationship between operational powerlessness and job satisfaction, we would assume that public professionals who cannot decide how best to implement a new policy will be more dissatisfied. When we look at client meaninglessness and job satisfaction, we would expect that public professionals who feel that a new policy is not helping clients will be more dissatisfied.

\section{Policy alienation and its relation to organizational commitment}

Besides the connection between policy alienation and job satisfaction, we can examine the causal links between policy alienation and organizational commitment. Similar to job satisfaction, organizational commitment is a complex, multifaceted construct, which is connected with employees' psychological state. In this research, we examine the commitment that employees of the labor office feel to their employer. That is, we investigate their 'attitude regarding the relationship between an employee 
and his/her workplace' (Goulet and Frank, 2002). We particularly focus on affective and normative commitment (Meyer, Allen and Smith, 1993).

Affective commitment is encouraged by work experiences 'that fulfil employees' psychological need to feel comfortable within the organization and competent in the work-role' (Allen and Meyer, 1990, p. 4). Employees with a high degree of affective commitment remain in an organization because they want to do so. They feel loyalty to their organization and feel a strong sense that they belong to their organization. When we consider the relationship between affective commitment and policy alienation, we assume that employees with low affective commitment to an organization that is being reformed will feel more alienated from an attempt at organizational reform (in each sub-dimension).

Normative commitment arises from socialization experiences that confirm the rightness of remaining loyal to an organization or simply from the receipt of benefits from it. These factors generate a sense of obligation within employees to reciprocate financial benefits or skill trainings (Allen and Meyer, 1990, p. 4). Essentially, employees with a high degree of normative commitment remain with an organization just because they feel they should. When we look at normative commitment and policy alienation, we would expect that employees with low normative commitment will also feel more alienated from an ongoing reform of the organization (in each sub-dimension). All these factors working together (policy alienation, job dissatisfaction and low organizational commitment) may lead to worse work performance and lower quality of services provided to clients (more in, e.g., Farmer, 2011; Cole, Panchanadeswaran and Daining, 2004).

\section{Goals, research questions and hypotheses}

The major goal of this article is to verify whether we can effectively use Tummers's validated scale for measurement of policy alienation under different conditions, that is, different history, different cultures, target groups, and public domains. We examine whether public professionals in the Czech labor offices are alienated from the policies they are expected to implement and whether this alienation leads to low job satisfaction and low organizational commitment. The first research goal of this article is to find out whether employees of the labor offices experience policy alienation and whether that can be attributed to the reform of the labor offices pursued by the government. In so doing, we ask the following question: to what degree are the several individual sub-dimensions of policy alienation noticeable among the employees of the labor offices?

Our second research goal is related to job satisfaction. We would like to find out whether or not job dissatisfaction among employees is attributable to alienation from the policy (in this case, from the reform). We ask the following question: to what extent is job satisfaction influenced by each of the sub-dimensions of policy alienation? Based upon our theory, we formulate the following hypotheses: (H1) The sub-dimensions of policy powerlessness negatively influence job satisfaction, 
and $(\mathrm{H} 2)$ the sub-dimensions of policy meaninglessness negatively influence job satisfaction. That is, the more alienated employees are, the more dissatisfied with their job they are.

The third research goal is related to organizational commitment. We would like to find out whether the organizational commitment of employees is influenced by policy alienation. We ask the following question: To what extent are affective commitment and normative commitment influenced by the sub-dimensions of policy alienation? Based upon our above-mentioned theory we formulate the following hypotheses: (H3) Sub-dimensions of policy powerlessness negatively influence affective and normative commitment, and (H4) Sub-dimensions of policy meaninglessness negatively influence affective and normative commitment. That is, the more alienated employees are, the less commitment with their organization they have.

\section{Methodology}

The above-mentioned goals and questions were answered by survey research. Usually, survey research is not easy to do in public administration. The researcher often faces a whole range of problems that undermine the representativeness of the sample and the validity of the results. The problems include obtaining a reliable sample frame, getting access to employees, ensuring a sufficient response rate and receiving frank and unbiased answers from the employees (Newman, Cherney and Head, 2017; Hammerschmid, Oprisor and Štimac, 2013; Veselý, Wellstead and Evans, 2014).

The research presented here consists of a cross-sectional survey of employees from the labor offices of the Czech Republic. A questionnaire was developed and distributed by the author. The survey was performed in September 2016 (i.e. five years after the implementation of the reform). Data was collected on only two days before employees were forbidden by management from filling out the questionnaire. The ban on cooperation with the survey was commanded by the director of the labor offices, without a specified reason. The questionnaire was distributed to 7,822 employees in the labor offices, all of whom were working with clients on a regular basis. We used computer-assisted web interviewing (CAWI). Contacts with respondents were obtained from the web page of the Ministry of Labor and Social Affairs, which provided a list of names and the basic positions of the employees of the labor offices. Because we were not able to get more information about employees (such as their age, education and more detailed information about their positions) we had to take a census. We received returns from 1,334 of the professionals, of whom 568 had had experience with the reform. Despite the problems with the realization of the survey, the response rate ( $18.4 \%$ after cleaning) was not significantly lower than in other similar surveys found in the literature (Hammerschmid, Oprisor and Štimac, 2013; Veselý, 2014).

Our questionnaire employed a validated scale for policy alienation, job satisfaction and organizational commitment. For the policy alienation variable, Tummers's (2012) 
validated scale was used. It has two major dimensions: powerlessness and meaninglessness, which are composed of five sub-dimensions: strategic powerlessness (3 items), tactical powerlessness (6 items), operational powerlessness (6 items), societal meaninglessness (4 items) and client meaninglessness (4 items). Before analyzing the gathered data, the internal consistency of the scales was examined and Cronbach's alpha for the scale and each sub-scale was determined (alphas were acceptable except the one for tactical powerlessness, 0.55 alpha). The detailed validated scale and its properties is available from the author on request.

For the variable on job satisfaction we used another validated scale created by Wright and Davis (2003). That is a general scale for measurement of job satisfaction which consists of four items. We obtained a 0.77 Cronbach's alpha for it. We used another validated scale devised by Meyer, Allen and Smith (1993) for measurement of organizational commitment in two dimensions, affective commitment (6 items) and normative commitment ( 6 items). For the scale of affective commitment, we obtained a 0.79 Cronbach's alpha and for the scale of normative commitment we obtained a 0.80 alpha.

On all three scales (policy alienation, job satisfaction and organizational commitment) responses were recorded using a five-point Likert-type scale (from 'strongly agree', coded 1, to 'strongly disagree', coded 5).

Our analysis is based on descriptive statistics, correlation (using Pearson's coefficient) and linear regression. First of all, to meet our first goal (determining whether professionals are alienated from the reform) we used descriptive statistics. To fulfill our second and third goals, we used correlation analysis and, for deeper understanding, regression analysis. In the regression analysis, we present two models. The first explores the relation between job satisfaction and policy alienation, and to what extent job satisfaction is influenced by each sub-dimensions of policy alienation. The second model discovers to what extent organizational commitment (a variable created by merging the two scales, affective and normative commitment) is influenced by each sub-dimension of policy alienation. In both models of regression, policy alienation is an independent variable.

\section{Results and discussions}

\subsection{Descriptive statistics}

The employees displayed a high degree of policy alienation (PA) (3.93 compared to 3.82 for the employees surveyed by Tummers, 2012). They reported a bit higher feeling of policy powerlessness than policy meaninglessness (4.05 vs. 3.76). It might be assumed that labor office employees felt a little more powerlessness based on how the reform was implemented than on the actual consequences of the reform for their clients. Results on both scales are rather high and are similar to those reported by Tummers (2012) for Dutch health-care professionals. 
Table 1: Mean of policy alienation, job satisfaction and organizational commitment

\begin{tabular}{lc}
\hline \multicolumn{1}{c}{ Variables } & Results (means) \\
\hline Strategic powerlessness & 4.67 \\
Tactical powerlessness & 4.34 \\
Operational powerlessness & 3.13 \\
Total powerlessness & 4.05 \\
Societal meaninglessness & 3.93 \\
Client meaninglessness & 3.62 \\
Total meaninglessness & 3.76 \\
Policy alienation & 3.93 \\
Job satisfaction & 2.67 \\
Affective commitment & 2.96 \\
Normative commitment & 3.39 \\
Total organizational commitment & 3.17 \\
\hline
\end{tabular}

N/Policy alienation $=568$ ( $1=$ not feel alienated, $5=$ definitely alienated $)$

$\mathrm{N} /$ Job satisfaction, organizational commitment $=1334$ (1 = definitely

satisfied/committed, 5 = definitely dissatisfied/uncommitted)

Source: Author's calculations

More detailed analysis reveals that from the total sample, the mean findings are 4.67 for strategic powerlessness, 4.34 for tactical powerlessness and 3.13 for operational powerlessness. Although operational powerlessness is objectively rather high, compared to the values observed for the other two types of powerlessness it is relatively low. A relatively low value for operational powerlessness was similarly reported by Tummers $(2012 ; 3.48)$. This result can partially be attributed to high self-perceived status among street-level bureaucrats and their 'substantial discretion in the execution of their work' as Lipsky $(1980$, p. 3) suggested in his book. It can mean that public professionals have a degree of autonomy and freedom in policy implementation. As for meaninglessness, the employees on average report higher feelings of societal meaninglessness (related to the fulfillment of the goals of the reform) (3.92) than feelings of client meaninglessness (3.62). Surprisingly, we do not find significant differences in the average of policy alienation between front-line staff and their direct superiors (3.95 vs 3.90). Perhaps both groups wished to be more involved in the design and implementation of the reform than they actually were.

We researched the degree of job satisfaction (JS) and organizational commitment (OC) for this article. According to our results, we can say that employees overall were dissatisfied with their jobs (2.67) and that they felt a low degree of OC (3.17). Employees demonstrate higher normative than affective commitment. This means that they do not feel a sense of obligation to reciprocate benefits from the organization.

More detailed analysis (in Table 2) reveals that employees who had experience with the reform are less satisfied than those who did not experience it. Surprisingly, feelings of organizational commitment do not differ between employees with and without experience with the reform. 
Table 2: Mean of job satisfaction and organizational commitment by experience with the reform

\begin{tabular}{lcc}
\hline & $\begin{array}{c}\text { Employees with experience } \\
\text { of the reform }\end{array}$ & $\begin{array}{c}\text { No experience } \\
\text { of the reform }\end{array}$ \\
\hline Job satisfaction & 2.71 & 2.64 \\
Organizational commitment & 3.17 & 3.18 \\
\hline $\mathrm{N}=1334$ /experience $=568$, no experience $=766(1=$ definitely satisfied/committed, \\
$5=$ definitely dissatisfied/uncommitted $)$
\end{tabular}

Source: Author's calculations

\subsection{Correlation analysis: the relationship among policy alienation, job satisfaction and organizational commitment}

Our results show a statistically significant correlation between PA and JS, i.e., the more alienated employees are, the more dissatisfied they are with their jobs $(\mathrm{r}=0.34$, $p<0.01)$. This confirms the findings of Tummers (2012, p. 522), who found that 'public professionals who score highly on policy alienation are indeed less satisfied with their job'. We will explore the relationship between JS and PA in more detail. There is a significant correlation between JS and all its sub-dimensions, except for strategic powerlessness (as we can see in Table 3). The most important relation is between operational powerlessness and job satisfaction (0.452, compared to only 0.190 in Tummers, 2012), i.e., the more operationally powerless employees feel, the more dissatisfied they are with their jobs. Client meaninglessness is also very important, so much so that we can claim that public professionals feel a need to provide valuable services to their clients in order to feel happy in their work.

As we mentioned above we found no difference in the perception of OC between employees who have experience with the reform and those who do not. However, we observed a relatively strong correlation between OC and PA, i.e., the more alienated employees are, the less commitment to their organization (the labor office) they feel $(\mathrm{r}=0.33, \mathrm{p}<0.01)$. More specifically (in Table 3), in the relationship between OC and the sub-dimensions of PA we found a significant correlation between them, again, except for strategic powerlessness (at least for affective commitment). The most important sub-dimensions in terms of their impact on OC are operational powerlessness $(\mathrm{r}=0.33)$ and client meaninglessness $(\mathrm{r}=0.28)$. We can also observe that the correlation between normative commitment and all sub-dimensions is higher than that for affective commitment (except for operational powerlessness). It can mean that public professionals who remain with an organization just because they feel they should are more alienated from the policy.

In general, we can assert that policy alienation negatively influences both job satisfaction and organizational commitment. The most obvious impact results from feelings of operational powerlessness and client meaninglessness. It must be noted that these correlations do not necessarily mean that there is a direct causal link between the two. Nevertheless, the data provide sufficient evidence for the importance of involving employees into policy design and implementation. We can say that as public 
Table 3: Correlation between sub-dimensions of policy alienation and job satisfaction and organizational commitment

\begin{tabular}{lccccc}
\hline \multicolumn{1}{c}{ Concept } & $\begin{array}{c}\text { Strategic } \\
\text { powerlessness }\end{array}$ & $\begin{array}{c}\text { Tactical } \\
\text { powerlessness }\end{array}$ & $\begin{array}{c}\text { Operational } \\
\text { powerlessness }\end{array}$ & $\begin{array}{c}\text { Societal } \\
\text { meaningless. }\end{array}$ & $\begin{array}{c}\text { Client } \\
\text { meaningless. }\end{array}$ \\
\hline Job satisfaction & n.s. & $0,122^{*}$ & $\mathbf{0 , 4 5 2 ^ { * * }}$ & $0,209^{* *}$ & $0,283^{* *}$ \\
Organizational commitment & $0.093^{*}$ & $0.177^{* *}$ & $\mathbf{0 . 3 3 3 ^ { * * }}$ & $0.222^{* *}$ & $0.282^{* *}$ \\
Affective commitment & n.s. & $0.105^{*}$ & $\mathbf{0 . 3 0 0 ^ { * * }}$ & $0.146^{* *}$ & $0.209^{* *}$ \\
Normative commitment & $0.113^{* *}$ & $0.214^{* *}$ & $\mathbf{0 . 2 9 2}^{* *}$ & $0.254^{* *}$ & $0.296^{* *}$ \\
\hline
\end{tabular}

${ }^{* *} p<0.01 ;{ }^{*} p<0.05 ;$ n.s. $=$ non-significant

Source: Author's calculations

professionals, they expect a high degree of discretion and autonomy and that the services they provide to their clients should be valuable.

\subsection{Regression analysis: the influence of sub-dimensions of policy alienation on job satisfaction and organizational commitment}

As we mentioned above in discussing our goals, we need more detailed and deeper analysis to explain the complicated links between policy alienation and the two variables of job satisfaction and organizational commitment. We used regression analysis to provide that explanation. We present here two models, one of them related to job satisfaction, and the other to organizational commitment.

According to the results displayed in Table 4, we observe that policy alienation explains $21 \%$ of the variability in job satisfaction. Again, we observe the strong influence of operational powerlessness, for which the coefficients are the highest $(B=$ 0.521 , Beta $=0.417$ ), compared to the influence of client meaninglessness. An explanation for the strong relation between operational powerlessness and job satisfaction can be found in the theoretical framework of 'street-level bureaucrats' (Lipsky, 1980), which suggests that public professionals expect freedom and autonomy in making and implementing policy. Thus, we can reasonably expect that if a new policy is imposed top-down instead of bottom-up, public professionals are likely to be more dissatisfied with their jobs.

Table 4: First model: relation between policy alienation and job satisfaction

\begin{tabular}{llcccc}
\hline $\begin{array}{l}\text { Model 1 - relation between policy } \\
\text { alienation and job satisfaction }\end{array}$ & \multirow{2}{*}{ B } & \multirow{2}{*}{ Beta } & \multicolumn{3}{c}{ Correlation } \\
\cline { 5 - 7 } Operational powerlessness & $0.521^{* *}$ & 0.417 & 0.452 & 0.384 & 0.367 \\
Client meaninglessness & $0.150^{*}$ & 0.133 & 0.283 & 0.119 & 0.106 \\
Societal meaninglessness & 0.003 (n.s.) & 0.003 & 0.209 & 0.002 & 0.002 \\
Tactical powerlessness & -0.068 (n.s.) & -0.042 & 0.122 & -0.039 & -0.035 \\
Strategic powerlessness & -0.042 (n.s.) & -0.30 & 0.074 & -0.029 & -0.026 \\
\hline Signification & & & & & 0.000 \\
Adjusted R2 & & & & & 0.21 \\
\hline
\end{tabular}

${ }^{* *} p<0.01 ;{ }^{*} p<0.05 ;$ n.s. $=$ non-significant

Source: Author's calculations 
To achieve our third goal for this research, determining whether affective and normative commitment is influenced by the level of each sub-dimension of policy alienation, we can turn to the data in Table 5. We find that this relationship is not as strong as the one with job satisfaction. Policy alienation explains only $13 \%$ of the variability in organizational commitment. We can say that policy alienation influences feelings of loyalty and obligation to the organization, but not to the same extent as it does job satisfaction. As with job satisfaction, the most important sub-dimension influencing $\mathrm{OC}$ is operational powerlessness, and the second most significant variable is client meaninglessness.

Employees who had experience with the reform and those who did not showed very little difference in feelings of organizational commitment based on policy alienation, as we saw in Table 2. A possible explanation is that organizational commitment is more dependent on the particular organization than on a particular policy. Therefore, we assume that feelings of loyalty and obligation to an organization are more connected with the leadership of the institution than with how policy is made.

Table 5: Second model: relation between policy alienation and organizational commitment

\begin{tabular}{llcccc}
\hline Model 2 - relation between policy alien- & \multirow{2}{*}{ B } & \multirow{2}{*}{ Beta } & \multicolumn{3}{c}{ Correlation } \\
\cline { 5 - 7 } ation and organizational commitment & & & Zero-order & Partial & Part \\
\hline Operational powerlessness & $0.245^{* *}$ & 0.249 & 0.333 & 0.229 & 0.219 \\
\hline Client meaninglessness & $0.139^{*}$ & 0.155 & 0.282 & 0.133 & 0.124 \\
Tactical powerlessness & 0.063 (n.s.) & 0.050 & 0.177 & 0.044 & 0.041 \\
Societal meaninglessness & 0.026 (n.s.) & 0.030 & 0.222 & 0.026 & 0.024 \\
Strategic powerlessness & -0.034 (n.s.) & -0.031 & 0.093 & -0.029 & -0.027 \\
\hline Signification & & & & & 0.000 \\
Adjusted R2 & & & & & 0.13 \\
\hline
\end{tabular}

${ }^{* *} p<0.01 ;{ }^{*} p<0.05 ;$ n.s. $=$ non-significant

Source: Author's calculations

Surprisingly, in both models we can observe an opposite influence of strategic powerlessness. This relation indicates that strategic powerlessness does not negatively affect either satisfaction or organizational commitment. In this analysis, the relationships of JS and OC with strategic powerlessness are not significant. We can assert that strategic powerlessness has no impact on job satisfaction or on organizational commitment. Also, very small or no impact connected with tactical powerlessness and societal meaninglessness is evident in both models.

\section{Conclusions}

In this article, we examined whether we can use Tummers's validated scale for measurement of policy alienation under different conditions. Based on our results, we assume that the concept of policy alienation and its measured results in terms of job satisfaction and organizational commitment have theoretical, methodological and practical value. This approach to research is theoretically unique, because it links pol- 
icy and psychology. That is, it links the policy-making process and the implementation of policy with the feelings and perceptions of public professionals. According to our results, we can expect that a new policy that is imposed top-down instead of bottom-up will cause public professionals to feel more dissatisfied in their jobs and feel low commitment to their organization. Therefore, we can confirm that both of these dimensions of policy alienation, policy powerlessness and policy meaninglessness, are very important to employees of the labor offices and negatively influence their feelings as public professionals. Our findings are similar to the results of Tummers in the Netherlands.

It is also unique in terms of its methodology. The policy alienation scale enables us to compare the level of policy alienation of public employees with other theories. We discovered that policy alienation as a whole explains $21 \%$ of the variation in job satisfaction and $13 \%$ of the variation in organizational commitment. We can expect that the way a policy is designed and implemented has a higher impact on job satisfaction than it does on organizational commitment.

Our findings also have practical implications because it helps us to understand why policies fail. The measured levels of policy powerlessness and meaninglessness are very important predictors of the policy failure or success and should be taken into account as policy is formulated. Politicians should understand that introducing a new policy without prior communication with public professionals can lead to alienation and low job satisfaction.

As with all studies, this research has several limitations. First, involving employees in decision-making might have some pitfalls. The expectations of public professionals cannot be met, it can be difficult for the government to manage a great deal of different interests and opinions. It is also possible that employees do not want to participate in the policy-making process. Needless to say, there are top-down created policies that can be successful (especially those with a technical problem requiring a clear solution). However, our assumption in this article is that public policies that depend on experienced and skilled public professionals should include them in decision-making process of the new policy.

Secondly, we cannot always claim that higher policy alienation inevitably leads to higher job dissatisfaction and lower organizational commitment. To fully explain this relationship, we should investigate successful policies and find out whether public professionals feel less (or even no) alienation from the policy and how strongly each of the sub-dimensions of policy alienation is related to job satisfaction and organizational commitment.

Thirdly, we should interpret the results of our research in light of its limited context and sample size. However, although the data must be interpreted with some caution, there is no sign that it is systemically biased or that its quality differs from other similar surveys (Tummers, 2012 and 2013; Veselý, 2014).

As mentioned above, research into policy alienation has theoretical, methodological and practical significance. Future research should test the validity of the Tummers 
scale and explore relationships between policy alienation and other workplace issues. It should also evaluate the impact of successful policies using a similar scale. Recently, for example, a new scale of policy alienation has been developed by Nadine van Engen (2017). She originated the concept of 'general policy alienation'. Her scale measures overall cognitive disconnectedness from government policies, i.e. how much people identify or do not identify with government policies in general.

\section{References:}

1. Allen, N.J. and Meyer, J.P., 'The Measurement and Antecedents of Affective, Continuance and Normative Commitment to the Organization', 1990, Journal of Occupational and Organizational Psychology, vol. 63, pp. 1-18.

2. Aiken, M. and Hage, J., 'Organizational Alienation: A Comparative Analysis', 1966, American Sociological Review, vol. 31, no. 4, pp. 497-507.

3. Asencio, H., 'Leadership, Trust and Organizational Performance in the Public Sector', 2016, Transylvanian Review of Administrative Sciences, Special Issue, pp. 5-22.

4. Blauner, R., Alienation and Freedom: The Factory Worker and His Industry, Chicago: University of Chicago Press, 1964.

5. Bovens, M. and 't Hart, P., Understanding Policy Fiascoes, New Brunswick, New Jersey: Transaction Publishers, 2011.

6. Bovens, M., 't Hart, P. and Peters, B.G., Success and Failure in Public Governance: A Comparative Analysis, Cheltenham, Northampton: Edward Elgar Publishing, 2001.

7. Cole, D., Panchanadeswaran, S. and Daining, C., 'Predictors of Job Satisfaction of Licensed Social Workers: Perceived Efficacy as a Mediator of the Relationship between Workload and Job Satisfaction', 2004, Journal of Social Service Research, vol. 31, no. 1, pp. $1-12$.

8. DeHart-Davis, L. and Pandey, S.K., 'Red Tape and Public Employees: Does Perceived Rule Dysfunction Alienate Managers?', 2005, Journal of Public Administration Research and Theory, vol. 15, no. 1, pp. 133-148.

9. Elpers, K. and Westhuis, D.J., 'Organizational Leadership and its Impact on Social Workers' Job Satisfaction: A National Study', 2008, Administration in Social Work, vol. 32, no. 3, pp. 26-43.

10. Farmer, D., 'Increasing Job Satisfaction among Social Workers', 2011, International Journal of Humanities and Social Science, vol. 1, no. 1, pp. 1-8.

11. Goulet, L.R. and Frank, M.L., 'Organizational Commitment across Three Sectors: Public, Non-Profit, and For-Profit', 2002, Public Personnel Management, vol. 31, no. 2, pp. 201-210.

12. Hammerschmid, G., Oprisor, A. and Štimac, V., 'COCOPS Executive Survey on Public Sector Reform in Europe: Research Report', 2013.

13. Kalekin-Fishman, D., 'Unravelling Alienation: From an Omen of Doom to a Celebration of Diversity', in Quah, S.R. and Sales, A., (eds.), International Handbook of Sociology, London: Sage Publication, 2000, pp. 387-419.

14. Kotrusová, M. and Výborná K., 'A Policy Fiasco: The Institutional (Non-)Reform of Czech Public Employment Services in 2011', 2015, Central European Journal of Public Policy, vol. 9, no. 1, pp. 148-158. 
15. Lipsky, M., Street-level Bureaucracy: Dilemmas of the Individual in Public Service, New York: Russell Sage Foundation, 1980.

16. Marx, K., Ekonomicko-filozofické rukopisy z roku 1844 [Economic and Philosophical Manuscripts of 1844], Praha: Státní nakladatelství politické literatury, 1961.

17. McConnell, A., 'What is Policy Failure? A Primer to Help Navigate the Maze', 2015, Public Policy and Administration, vol. 30, no. 3-4, pp. 221-242.

18. Mendes, L., Carlos, V. and Lourenco, L, 'The Influence of TQM on Organizational Commitment, Organizational Citizenship Behaviours, and Individual Performace', 2014, Transylvanian Review of Administrative Sciences, Special Issue, pp. 111-130.

19. Meyer, J.P., Allen, N.J. and Smith, C.A., 'Commitment to Organizations and Occupations: Extension and Test of a Three-Component Conceptualization', 1993, Journal of Applied Psychology, vol. 78, no. 4, pp. 538-551.

20. Newman, J., Cherney, A. and Head, B.W., 'Policy Capacity and Evidence-Based Policy in the Public Service', 2017, Public Management Review, vol. 19, no. 2, pp. 157-174.

21. Seeman, M., 'On the Meaning of Alienation', 1959, American Sociological Review, vol. 24, no. 6, pp. 783-791.

22. Tummers, L., 'Policy Alienation of Public Professionals: The Construct and Its Measurement', 2012, Public Administration Review, vol. 72, no. 4, pp. 516-525.

23. Tummers, L., Policy Alienation and the Power of Professionals: Confronting New Policies, Cheltenham: Edward Elgar Publishing, 2013.

24. Tummers, L., Bekkers, V. and Steijn, B., 'Policy Alienation of Public Professionals: Application in a New Public Management Context', 2009, Public Management Review, vol. 11, no. 5, pp. 685-706.

25. Tummers, L., Bekkers, V. and Steijn, B., 'Policy Alienation of Public Professionals: A Comparative Case Study of Insurance Physicians and Secondary School Teachers', 2012, International Journal of Public Administration, vol. 35, no. 4, pp. 259-271.

26. van Engen, N., 'A Short Measure of General Policy Alienation: Scale Development Using a 10-Step Procedure', 2017, Public Administration, vol. 95, no. 2, pp. 512-526.

27. Veselý, A., 'The Profile and Work of Officials in Central and Regional Administration Compared: The Case of the Czech Republic', 2014, NISPAcee Journal of Public Administration and Policy, vol. 7, no. 1, pp. 107-128.

28. Veselý, A., Wellstead, A. and Evans, B., 'Comparing Sub-National Policy Workers in Canada and the Czech Republic: Who Are They, What They Do, and Why It Matters?', 2014, Policy and Society, vol. 33, no. 2, pp. 103-115.

29. Wright, B.E. and Davis, B.S., 'Job Satisfaction in the Public Sector: The Role of the Work Environment', 2003, The American Review of Public Administration, vol. 3, no. 1, pp. 70-90. 